\title{
A case of mobile mitral annular mass
}

\author{
Mobil mitral anuler kitle olgusu \\ Özgül Uçar Elalmış, Ahmet Karagöz*, İlker Şahin, Özlem Keskin, Bengi Başer
}

Department of Cardiology (Assoc. Prof. Ö. U. Elalmış, MD, İ. Şahin, MD), Ankara Numune Education and Research Hospital, TR-06100 Ankara, Department of Cardiology (Assoc. Prof. A. Karagöz, MD, Prof. B. Başer, MD), Department of Cardiovascular Surgery (Ö. Keskin, MD), Giresun University Education and Research Hospital, TR-28100 Giresun

\begin{abstract}
Mitral annular calcification is a chronic, degenerative process of the mitral valve fibrous ring, primarily involving the posterior annulus. This report presented a case of mitral annular calcification with mobile components which was found incidentally during TTE. The echocardiographic differential diagnosis of a mass includes thrombus, vegetation, primary or secondary cardiac tumor and extensive mitral annular calcification with mobile components. A calcified, mobile mass attached to the posterior mitral annulus should raise the suspicion of extensive mitral annular calcification. Serial echocardiograms in our patient documented that these mobile elements can resolve rapidly. The optimal treatment or clinical approach to this clinical condition remains to be established.
\end{abstract}

Keywords: Mobile, mitral, annular mass

\section{Özet}

Mitral anuler kalsifikasyon özellikle posterior anulusu etkileyen, mitral kapağın fibröz halkasının kronik ve dejeneratif bir hastalığıdır. Bu yazıda transtorasik ekokardiyografi sırasında tesadüfen saptanan mobil komponentleri olan mitral anuler kalsifikasyon vakası sunulmaktadır. Kitlenin ekokardiyografik ayırıcı tanısı, trombüs, vejetasyon, primer ve sekonder kardiyak tümörler ve mobil komponentler ile birlikte yaygın mitral anüler kalsifikasyonu içermektedir. Posterior mitral anulusa yapışık kalsifiye ve mobil bir kitle, yaygın mitral anuler kalsifikasyon tanısını akla getirmelidir. Hastamızda seri ekokardiyografik incelemeler sonucunda bu mobil elementlerin hızlıca ortadan kaybolabileceği gösterilmiştir. Bu klinik durumda uygulanacak optimal tedavi veya klinik yaklaşım biçiminin yeni vakalar ile pekiştirimesi gerekmektedir.

Anahtar sözcükler: Mobil, mitral, anuler kitle

Geliş tarihi/Received: July 12, 2013; Kabul tarihi/Accepted: February 03, 2014

\section{*Corresponding author:}

Dr. Ahmet Karagöz, Kardiyoloji Anabilim Dalı, Giresun Üniversitesi Eğitim ve Araştırma Hastanesi, TR-28100 Giresun. E-mail: drahmetkgz@hotmail.com

\section{Introduction}

Mitral annular calcification is a chronic degenerative process of the mitral valve fibrous ring, primarily involving the posterior annulus. It is easily diagnosed by 2-D echocardiography as a echodense structure at the posterior mitral valve or along the mitral annulus. Usually asymptomatic, massive calcification can distort the mitral leaflets sufficient to cause mitral valvular dysfunction [1]. Occasionally mobile components can be seen on mitral annular calcification, which can be erroneously diagnosed as a thrombus, vegetation, abscess or tumor leading to unnecessary cardiac surgery. In this report we present a case of intracardiac mass incidentally found in the echocardiographic 
examination which was later diagnosed as mitral annular calcification.

\section{Case report}

A 65 year-old man presented to cardiology output clinic for a control examination. He had an inferior wall myocardial infarction two months ago. He received thrombolytic therapy with r-tPA and one-week later, a drug eluting stent was inserted to proximal right coronary artery. He was on aspirin and clopidogrel therapy since then. He had a wellcontrolled hypertension. Five years ago, he had the diagnosis of colon cancer, which was cured by resection only. A recent colonoscopy revealed normal findings. On physical examination, a grade 1-2/6 pansystolic murmur was heard at the cardiac apex. Twelvelead electrocardiogram revealed sinus rhythm with inferior Q-waves. Blood tests including renal function tests and tumor markers were normal. A transthoracic echocardiography (TTE) was ordered for the evaluation of the murmur and left ventricular systolic functions. TTE revealed hypokinesis of the inferior wall and mild-tomoderate mitral regurgitation. Posterior mitral annulus was calcified with a 1.9x1.9 cm sized, round, echodense, mobile mass on the left ventricular side (Figure 1). A following transesophageal echocardiography (TEE) also demonstrated that the mass was attached to the posterior mitral annulus. Left atrial appendage showed no thrombus. On differential diagnosis thrombus, vegetation, myxoma and mitral annular calcification with mobile components were considered.

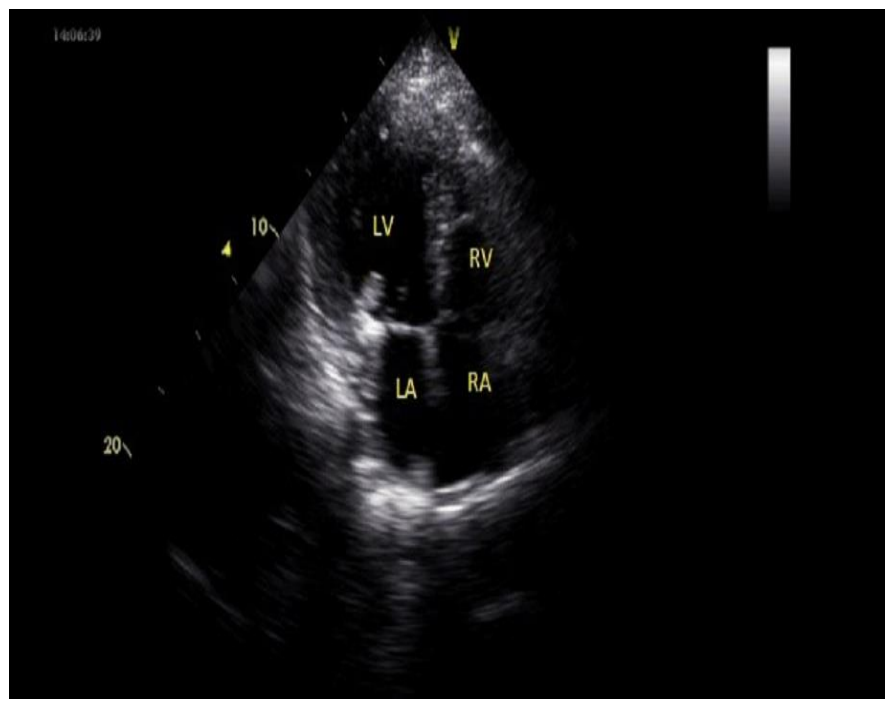

Figure 1. Mobile mass on the left ventricular side.

The patient had been on daily 300mg aspirin and 75mg clopidogrel therapy for 2 months and had no risk factors for thrombosis. Furthermore he was unwilling to use additional warfarin because of the bleeding risk. Five years earlier he was diagnosed as having colon cancer, but he was cure after a segmentary resection. On his recent control at gastroenterology clinic, everything was found normal. The patient had no fever and three sets of blood cultures were negative, so diagnosis of a infectious vegetation was unlikely. The localization was not typical for myxoma and finally, we decided to follow the patient by echocardiography for the course of the mass. A control TTE after one month showed that the mobility and the size of the mass were reduced. The mass was more echodense and calcific, and now seemed as a part of the mitral annulus. An echocardiogram at 6 weeks revealed fusion of the mitral annular calcification with the mass (Figure 2). Therefore we decided that the mobile mass was mitral annular calcification with mobile components. 


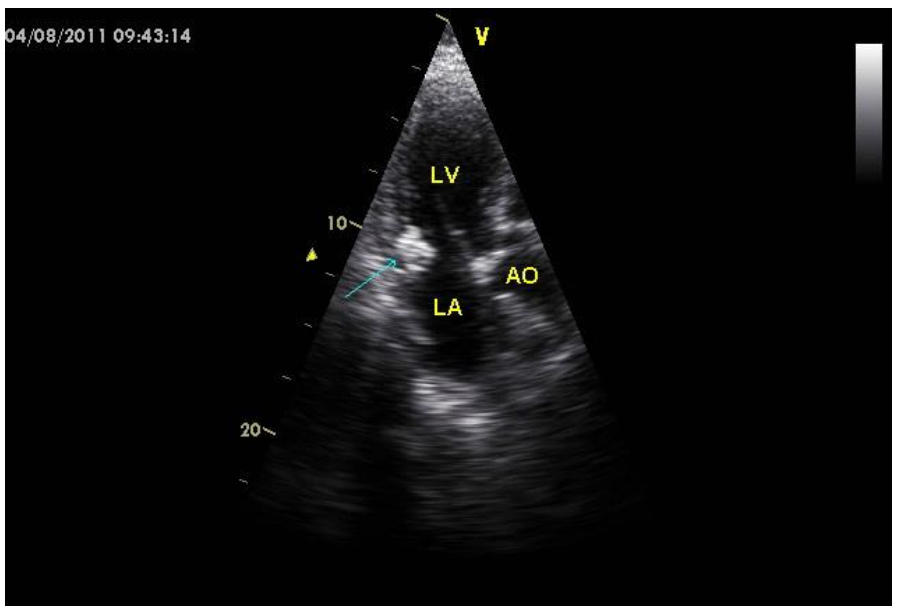

Figure 2. Fusion of the mitral annular calcification with the mass.

\section{Discussion}

This report presented a case of mitral annular calcification with mobile components which was found incidentally during TTE. The echocardiographic differential diagnosis of a mass includes thrombus, vegetation, primary or secondary cardiac tumor and extensive mitral annular calcification with mobile components. TTE is the first-line diagnostic test for intracardiac masses. TEE can provide additional value in assessing an intracardiac mass, especially when there is limited acoustic window. The most common intracardiac mass is a thrombus, but high density of the mass in our patient suggested calcifications. Moreover he was on dual antiplatelet therapy and had no atrial fibrillation. In the absence of fever, positive blood cultures or infectious laboratory examinations, valvular endocarditis was unlikely. Clinical signs of a relapsing colonic tumor was absent in our patient, therefore the most likely diagnosis was either myxoma or extensive mitral annular calcification. The most common primary tumor of the heart is myxoma, but myxomas seldom originate from cardiac valves. Despite adequate imaging, a surgical exploration and histologic confirmation were needed. However the patient had a recent acute inferior myocardial infarction which increased perioperative risk. In addition the patient also was reluctant for a open heart surgery. Therefore we decided to follow the patient by echocardiography. Echocardiographic examinations revealed gradual reduction in the size and the mobility of the mass with eventually fusion with the mitral annulus.

Mitral annular calcification is a chronic, degenerative process of the mitral valve fibrous ring, primarily involving the posterior annulus. It has identical risk factors with cardiovascular disease [2]. Mitral annular calcification is observed in 3-8\% of the population at authopsy [3] and is especially common in elderly patients and in patients with end-stage renal disease $[4,5]$.

Although the clinical course of mitral annular calcification is benign, it can be complicated by secondary infections, arrhythmias, mitral valvular regurgitation, stenosis or thromboembolism [6, 7]. Moreover it can mimick tumors, vegetations or thrombi. Our primary concern about following the patient conservatively was increased risk of stroke [8]. Harpaz et al. [9] followed 13 patients with mitral annular calcification and caseous necrosis conservatively over 3.8 years and stroke occured in none of the patients.

Although the precise composition and pathogenesis of the mobile components are unknown, the erosion of the endothelium overlying the mitral annular calcification may allow extrusion of calcium, which may then provide a nidus for thrombus formation. The mobile components detected by echocardiography are most likely calcium or thrombus. In reports in which the masses we surgically excised were predominantly calcium [10]. In some patients the response to anticoagulants suggested thrombi. In our patient the 
echoreflectivity of the mobile component was identical to that of the mitral annular calcification. Although this favors the mass being composed primarily of calcium, the composition of intracardiac masses can be difficult to diagnose by echocardiography. The natural history of these lesions is unknown, we cannot tell if this outcome was due to asymptomatic embolization or spontaneous healing.

In conclusion, a calcified, mobile mass attached to the posterior mitral annulus should raise the suspicion of extensive mitral annular calcification. Serial echocardiograms in our patient documented that these mobile elements can resolve rapidly. The optimal treatment or clinical approach to this clinical condition remains to be established.

\section{References}

1. Kato M, Nakatani S, Okazaki H, Tagusari O, Kitakaze M. Unusual appearance of mitral annular calcification mimicking intracardiac tumor prompting early surgery. Cardiology 2006; 106: 164-6.

2. Fox CS, Vasan RS, Parise H, Levy D, O'Donnell CJ, D'Agostino RB, Benjamin EJ; Framingham Heart Study. Mitral annular calcification predicts cardiovascular morbidity and mortality: The Framingham Heart Study. Circulation 2003; 107: 1492-6.

3. Pomerance A. Pathological and clinical study of calcification of the mitral valve ring. J Clin Pathol 1970; 23: 354-61.

4. Ribeiro S, Ramos A, Brandão A, Rebelo JR, Guerra A, Resina C, Vila-Lobos A, Carvalho F, Remédio F, Ribeiro F. Cardiac valve calcification in haemodialysis patients: Role of calcium-phosphate metabolism.Nephrol Dial Transplant 1998; 13: 2037-40.

5. Jesri A, Braitman LE, Pressman GS. Severe mitral annular calcification predicts chronic kidney disease. Int J Cardiol 2008; 128: 193-6.

6. Pounder DJ. Calcification of the mitral annulus and its complications. Am J Forensic Med Pathol 1982; 3: 109-13.

7. de Vrey EA, Scholte AJ, Krauss XH, Dion RA, Poldermans D, van der Wall EE, Bax JJ. Intracardiac pseudotumor caused by mitral annular calcification. Eur J Echocardiogr 2006; 7: 62-6.

8. Stein JH, Soble JS. Thrombus associated with mitral valve calcification. A possible mechanism for embolic stroke. Stroke 1995; 26: 1697-9.

9. Harpaz D, Auerbach I, Vered Z, Motro M, Tobar A, Rosenblatt S. Caseous calcification of the mitral annulus: A neglected, unrecognized diagnosis. J Am Soc Echocardiogr 2001; 14: 825-31.

10. Prasad NK, Alam M, Rosman HS, Silverman NA. Mitral Annular Calcification Mimicking an Intracardiac Mass. Echocardiography 1995; 12: 609-12. 